\title{
PERFORMANCE EVALUATION OF INDUSTRIAL BY- PRODUCTS AS SUSTAINABLE PRACTICE AGAINST THE EXPLOITATION OF VIRGIN MATERIALS
}

\author{
U. Johnson Alengaram, PhD CEng MICE ${ }^{1}$ \\ ${ }^{1}$ Associate Professor, Department of Civil Engineering, Faculty of Engineering, \\ University of Malaya,50603 Kuala Lumpur, Malaysia \\ ${ }^{1}$ Director, Centre for Innovative Construction Technology, Department of Civil \\ Engineering, University of Malaya,50603, Kuala Lumpur, Malaysia \\ Corresponding author's e-mail: johnson@um.edu.my
}

\begin{abstract}
The rise in population and competitiveness among growing economies to stamp their superiority are some of the prime reasons for natural materials to disappear rapidly. This research involves the utilization of industrial by-products, namely rice husk ash (RHA), fly ash (FA), palm oil fuel ash (POFA), palm oil clinker powder (POCP), oil palm shell (OPS), and palm oil clinker (POC) as alternatives in the development of both conventional and geopolymer concretes; notably, OPS was used as whole replacement for conventional crushed granite aggregate in the development of impact and blast resistant concrete. Scanning electron microscopy and X-ray diffraction analyses were used to characterize the microstructure of concrete. The results showed that incorporation of RHA, POFA and POCP up to $30 \%$ minimizes concrete deterioration and loss in compressive strength; OPS concrete with its ductile property proved its impact and blast resistant characteristics.
\end{abstract}

Keywords: Rice husk ash (RHA), fly ash (FA), palm oil fuel ash (POFA), palm oil clinker powder (POCP), oil palm shell (OPS), palm oil clinker (POC), compressive strength, concrete.

\section{INTRODUCTION}

\section{Background}

Fast growing world minds little about environmental sustainability; this has already led many nations to face serious consequences such as flooding, environmental catastrophe, depletion of ground water, lack of building materials etc. However, some of the developed and developing countries, non-governmental organization and individuals, including Microsoft Founder Bill Gates-conscious of such exploitation have raised alarms and there have been certain interest and investment on the utilization of alternative materials that could be utilized to replace virgin materials (Sumesh et al.2019). The duty of architects, engineers, researchers, and construction 
industry is vital to ensure reduction in over exploitation of conventional materials. Further, governing authorities to implement design and building guidelines that would have some desired effect on reserving some of the natural materials for next generations through the implementation of leadership in energy and environmental design (LEED) and green building index (GBI) is also having some positive effect (Blackwelder, A., 2019; Facility Executive, 2017). One of the means to introduce sustainable development in a small but meaningful way is through the utilization of locally available waste, industrial by-products or recyclable materials. There is no secret on this statistics that shows that the production of concrete devours about 27 billion tonnes of natural raw materials-which is equivalent of 4 tonnes of concrete per person per year (Celik, K. et al., 2015). Further, quarrying and mechanised process of mammoth quantities of aggregates, in addition to about 2 billion tonnes of cement manufactured every year is responsible for about 5-7\% of the global $\mathrm{CO}_{2}$ emissions (Benhelal, E. et al., 2013).

\section{Exploitation of Virgin Materials}

Accordingly, the problem is likely to get worse as it is foretold that by 2025 production of cement alone is likely to emit about 3.5 billion tonnes of $\mathrm{CO}_{2}$ (Shi, C. et al., 2011). To add wound to already injured legs of construction industry, it is predicted that by 2050, the manufacture of concrete manufacture will peak four times the level compared to the production as that of 1990 (Damtoft, J.S. et al., 2008).

As known, the main ingredients in concrete, namely coarse and fine aggregates constitute approximately $60-80 \%$ of the total volume, out of which coarse aggregates constitute alone, would amount to about $50-60 \%$. Alternative to conventional materials would have positive effect on global environment as it would pave way for reduction in excessive use of virgin materials. From another perspective, concrete industry accounts for $5-7 \%$ of all man-made carbon dioxide $\left(\mathrm{CO}_{2}\right)$ emissions (Benhelal, E. et al., 2013). This progressive emission of $\mathrm{CO}_{2}$ has reached to an alarming level and is expected to be expanded at a faster rate. According to Collins, F. (2013), about $820 \mathrm{~kg}$ of $\mathrm{CO}_{2}$ is being emitted for every $1000 \mathrm{~kg}$ of cement manufactured. Around half of these emissions are from decarbonation process in which $\mathrm{CO}_{2}$ is lost from the limestone $\left(\mathrm{CaCO}_{3}\right)$ to produce calcium oxide $(\mathrm{CaO})$ and the remaining is from the fuel used to fire the kiln at temperature of $1500{ }^{\circ} \mathrm{C}$ (Cao et al., 2016).

\section{Usage of Industrial By-Products}

In contrast, many industrial by-products are being dumped in an open field or in the vicinity of the factories that leads to pollution of ground water or nearby stream and vulnerable to land pollution. Some of these materials are underutilized; industrial byproducts, such as rice husk ash (RHA), fly ash (FA), palm oil fuel ash (POFA), palm oil clinker powder (POCP), oil palm shell (OPS), palm oil clinker (POC), steel slag, and incinerated bottom ash aggregates (IBAA) are some of promising materials that could be utilized as replacement for conventional materials. In this research, some of the above-mentioned materials have been used under three categories namely, cement 
replacement materials-either partially or wholly in normal concrete and geopolymer concrete (Alengaram, U.J. et al., 2016b; Bashar, I.I. et al., 2014; Bashar, I.I. et al., 2016; Islam, A. et al., 2015; Nayaka, R.R. et al., 2018; Ng, C. et al., 2018; Sumesh, M. et al., 2019; Sumesh, M. et al., 2018).

The second type of replacement is on the utilization of non-traditional material as sand replacement for conventional mining sand. The third replacement was done for coarse aggregate using POC and OPS as whole or partial aggregate replacement in concrete or masonry. Though OPS had been traditionally used in research as coarse aggregate in lightweight concrete, in this research, OPS has been used as whole replacement for conventional crushed granite aggregate in impact and blast resistant concrete; the blast resistant characteristics were analysed through blast tests on OPS concrete panels (Alengaram, U.J. et al., 2016b). Thus, three types of materials replacement make the concrete green and the methods of development of green concrete could be adapted in small scale for implementation through commercialization where the resources are available in plenty. In addition, the durability aspect of recycled concrete aggregates (RCA) with supplementary cementitious materials (SCM) investigated in this research could be seen as another aspect on the application of SCM for construction and demolition waste as a potential recyclable material (Alnahhal, M.F. et al., 2018b).

\section{Salient Features of Projects Using Industrial By-Products}

Using some of the above-mentioned materials, one low cost house ( $\mathrm{LCH}$ ) was constructed to demonstrate to the public on the viable alternative materials and suitability of such sustainable materials to replace the conventional materials; in another project, OPS was used as blast resistant aggregate in OPS concrete (OPSC) and the blast resistant concrete was developed and tested. The effectiveness of Malaysian ashes - SCM as pozzolanic materials was investigated for durability aspect on recycled concrete aggregate on concrete using partial replacement for conventional cement. Finally, the usage of locally available industrial materials was used to develop geopolymer concrete.

\section{MATERIALS}

\section{Binders}

Ordinary Portland cement (OPC) with strength grade of $42.5 \mathrm{MPa}$ confirming to ASTM C150 was used. The pozzolanic industrial by-product ashes such as rice husk ash (RHA), palm oil fuel ash (POFA), and palm oil clinker powder (POCP) were used as fully and partially replacement of OPC to produce green binding material for concrete. The particle size distribution and particle shapes are shown in Figure 1 and Figure 2. Though there was no significant difference of particle size distribution among these pozzolans as shown in Figure 1, notable variation in particle shape was found from SEM results (Figure 2). The chemical and physical properties of these pozzolans are shown in Table 1 and Table 2, respectively. According to ASTM C618, RHA, POFA and POCP are defined as pozzolanic materials and suitable; thus, these 
materials could be considered by construction industry as an ideal replacement for OPC.

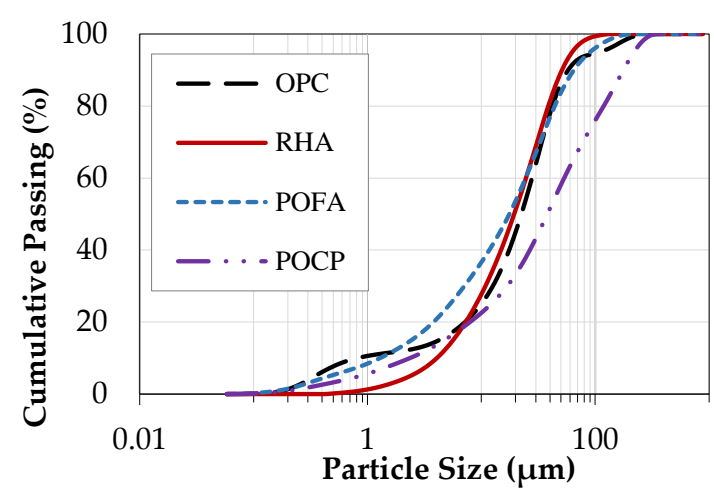

Figure 1. Particle size distribution of pozzolans

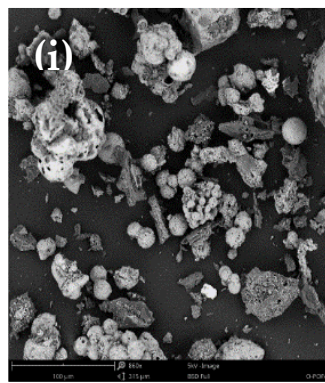

(c) POFA (i) before

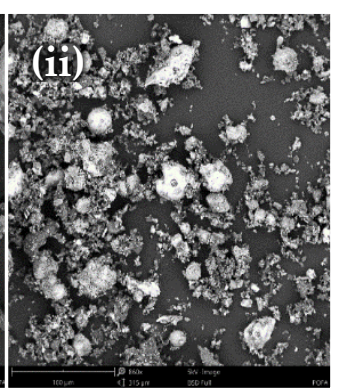

(ii) after grinding

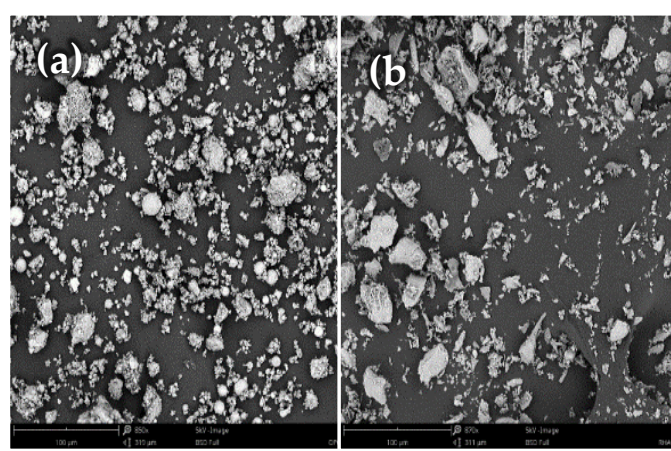

(a) OPC; (b) RHA

Figure 2. SEM and Physical appearance of pozzolans

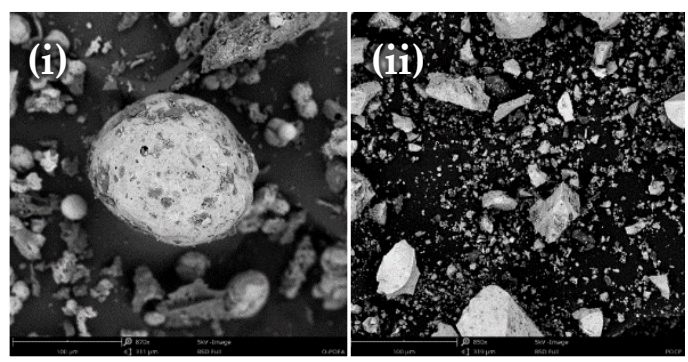

(d) POCP (i) before and (ii) after grinding

Figure 2 (cont'd). SEM and Physical appearance of pozzolans

Table 1. Chemical compositions (weight \%) of OPC, RHA, POFA and POCP

\begin{tabular}{lccclclll}
\hline $\begin{array}{l}\text { Chemical } \\
\text { compositions }\end{array}$ & $\mathrm{SiO}_{2}$ & $\mathrm{Al}_{2} \mathrm{O}_{3}$ & $\mathrm{Fe}_{2} \mathrm{O}_{3}$ & $\mathrm{SiO}_{2}+\mathrm{Al}_{2} \mathrm{O}_{3}+\mathrm{Fe}_{2} \mathrm{O}_{3}$ & $\mathrm{CaO}$ & $\mathrm{MgO}$ & $\mathrm{SO}_{3}$ & $\begin{array}{l}\text { Loss on } \\
\text { Ignition }\end{array}$ \\
\hline OPC & 21.00 & 5.90 & 3.40 & 30.30 & 64.7 & 2.50 & 2.40 & 0.90 \\
RHA & 91.00 & 0.35 & 0.41 & 91.76 & 0.49 & 0.81 & 1.21 & 4.81 \\
POFA & 64.17 & 3.73 & 6.33 & 74.23 & 5.80 & 3.46 & 0.74 & 11.56 \\
POCP & 60.29 & 5.83 & 4.71 & 70.83 & 3.28 & 4.20 & 0.31 & 5.23 \\
Class F & & & & 70 (min.) & & & 5 (max.) & 12 (max.) \\
\hline
\end{tabular}

Table 2. Physical properties of OPC, RHA, POFA and POCP

\begin{tabular}{|c|c|c|c|}
\hline Physical properties & $\begin{array}{l}\text { Specific gravity } \\
\left(\mathrm{g} / \mathrm{cm}^{3}\right)\end{array}$ & $\begin{array}{l}\text { Retained on } 45-\mu \mathrm{m} \text { sieve } \\
(\%)\end{array}$ & $\begin{array}{l}\text { Median } \\
\text { size }(\mu \mathrm{m})\end{array}$ \\
\hline OPC & 3.14 & 13.6 & 22.47 \\
\hline RHA & 2.03 & 1.70 & 19.41 \\
\hline POFA & 2.14 & 11.6 & 17.62 \\
\hline POCP & 2.53 & 29.0 & 37.97 \\
\hline ASTMC618 class F & & $34 \%$ (max.) & \\
\hline
\end{tabular}


RHA is produced from the paddy industry; normally it is done by burning rice husk $(\mathrm{RH})$ for generating heat to dry paddy and also electricity. This is a routine process in rice mill that generates RHA of about one-fourth of $\mathrm{RH}$ after burning at $180^{\circ} \mathrm{C}$ temperature (approx.). Large quantities of RHA are being dumped in open fields in the vicinity of the factory that causes land pollution and small quantities of RHA being used by farmers as fertilizer.

Like RHA, other potential industrial by-products, namely, palm oil fuel ash (POFA), palm oil clinker (POC) and palm oil clinker powder (POCP) are available abundantly that could be obtained from the palm oil industry. The mix of oil palm shell (OPS) and palm oil fibre (POF) are burnt in boiler at $500^{\circ} \mathrm{C}-800^{\circ} \mathrm{C}$ temperature in palm oil mill to produce electricity. The end-product from the boiler are mixture of POFA and POC. Both end-by-products have no practical use other than land-filling.

However, as seen from Table 1, RHA, POFA and POCP are good sources of $\mathrm{SiO}_{2}$ which is a prime chemical compound to produce $\mathrm{C}-\mathrm{S}-\mathrm{H}$ in concrete. RHA contains 90\% and POFA, POCP contain about $64 \%$ of $\mathrm{SiO}_{2}$. POFA, RHA and POCP enhance durability of concrete material (Alnahhal, M.F. et al., 2018b; Kabir, S.M.A. et al., 2017) by consumption of $\mathrm{Ca}(\mathrm{OH})_{2}$ during pozzolanic reaction (Lothenbach, B. et al., 2011). Therefore, from environmental and engineering aspect, industrial by-productsRHA, POFA and POCP could be used as either whole or partial replacement for OPC.

POFA was processed in laboratory further in order to obtain sufficient fineness and to improve its reactivity. Firstly, the collected POFA was dried in an oven at $105 \pm 5^{\circ} \mathrm{C}$ for $24 \mathrm{~h}$ since it was kept in an open area in the factory. Secondly, the dried POFA was sieved through $300-\mu \mathrm{m}$ sieve to eliminate the coarse particles and impurities. Finally, the POFA was ground using a Los Angeles abrasion machine with a speed of about 33 revolution per minute for 30,000 cycles.

Large chunks of palm oil clinker (POC) collected from palm oil mill have flaky, porous, and irregular shapes, and then these are crushed to smaller sizes to segregate coarse and fine POC aggregates; then the finer portion of POC aggregates that passes through $2.36 \mathrm{~mm}$ are ground to obtain POCP; the grinding process adapted for POCP was similar to that of POFA. Figure 2 shows the SEM image of POCP before and after grinding process at the same magnification factor. After grinding, the amount of POCP retained on $45-\mu \mathrm{m}$ sieve was $29 \%$, which confirms the requirements of ASTM C618 to be used as pozzolanic material. Figure 2 shows the physical appearance of OPC compared to RHA, POFA and POCP.

\section{Aggregates}

Oil palm shells (OPS) were used as whole replacement of conventional coarse in the OPSC panels that were tested for impact and blast loads; likewise, in the development of pavement blocks for low cost house, OPS were used as whole replacement of conventional crushed granite aggregates in the geopolymer concrete. 
OPS obtained from an oil palm mill, has a compacted bulk density of $620 \mathrm{~kg} / \mathrm{m}^{3}$. It is $890 \mathrm{~kg} / \mathrm{m}^{3}$ lower than the crushed granite aggregates which was used in this study. The physical characteristics of OPS are given in

Table 3 and as seen from the comparison between OPS and crushed granite aggregates, the bulk density and aggregate impact value of the former are lower than the latter. The high water absorption of OPS is attributed to micro pores on the surface of OPS. Lower aggregate impact value $(3.91 \%)$ of OPS indicates higher ductile property compared to granite. Figure 3 (a) and (b) show physical and microscopic appearance of OPS. The existence of fibre in OPS attributes to transmit stress energy into concrete and thus enhance ductility of concrete (Alengaram, U.J. et al., 2016b). Figure 3 (b) shows rough surface of OPS that helps in bonding with concrete matrix.

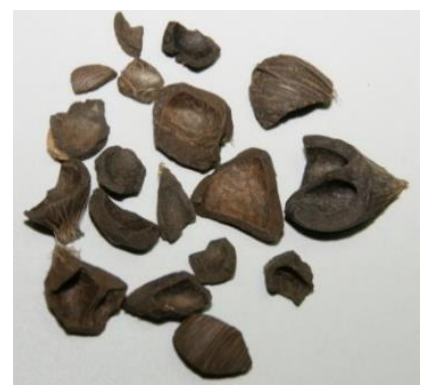

(a)

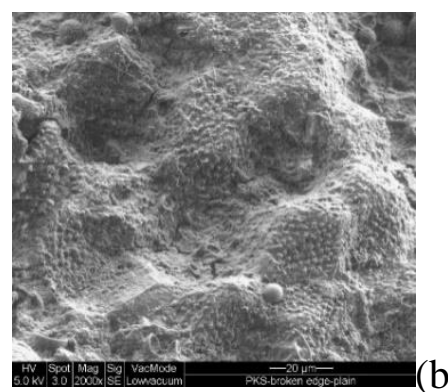

(b)

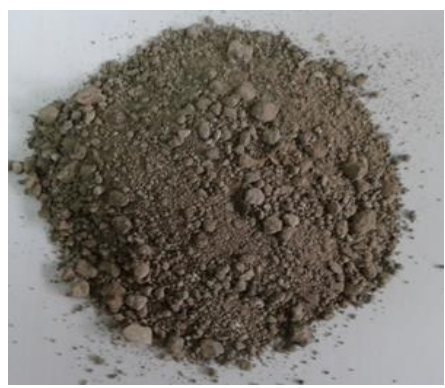

Figure 4. Incinerated bottom aggregate ash

Figure 3. (a) Oil palm shell (OPS) and (b) SEM image of broken edge of OPS (Alengaram, U.J. et al., 2016b)

Table 3: Physical properties of aggregates

\begin{tabular}{lll}
\hline Properties & Crushed granite & OPS \\
\hline Thickness $(\mathrm{mm})$ & 15 & $0.7-3.50$ \\
Bulk density $\left(\mathrm{kg} / \mathrm{m}^{3}\right)$ & 1510 & 620 \\
Specific gravity $(\mathrm{saturated}$ surface dry) & 2.67 & 1.27 \\
Fineness modulus & 6.57 & 6.24 \\
Water absorption -1 hour $(\%)$ & $<1$ & $10-12$ \\
Water absorption $-24 \mathrm{hr}(\%)$ & $<1$ & 25 \\
Aggregate impact value $(\%)$ & 16.8 & 3.91 \\
\hline
\end{tabular}

The physical properties of IBAA, namely the specific gravity and $24 \mathrm{~h}$ water absorption were found as 2.07 and $17.40 \%$, respectively; Figure 4 shows the physical appearance of IBAA used as partial fine aggregates in the development of blocks.

\section{EXPERIMENTAL RESULTS}

During the last two decades, Centre for Innovative Construction Technology (CICT), Department of Civil Engineering, Faculty of Engineering, University of Malaya, Malaysia has been involved in research and consultancy projects on the utilization of 
industrial wastes and by-products in the development of technology that could be ultimately used in building products. Few of the highlighted research outcomes are discussed below.

\section{Carbon-Footprint of Industrial By-Products}

Islam, A. et al. (2015) and Alnahhal, M.F. et al. (2018a) investigated $\mathrm{CO}_{2}$ emission $\left(\mathrm{CO}_{2}-\mathrm{e}\right)$ from the production of concrete using industrial by-product and recycle aggregate (RA), respectively. It was reported that about 52-61\% of $\mathrm{CO}_{2}$-e reduction by using geopolymer concrete compared to conventional concrete due to replacement of cement by industrial by-product POFA. Further, the replacement of granite by OPS in concrete reduced $42-52 \%$ of $\mathrm{CO}_{2}$-e compared to granite in concrete (Islam, A. et al., 2015). Similar research outcome was reported by McLellan, B.C. et al. (2011) that 44$64 \%$ of $\mathrm{CO}_{2}$-e can be reduced by geopolymer technology in concrete, though economically the cost of geopolymer concrete production was estimated twice that of conventional concrete under Australian context. Table 4 shows significance of using RHA, POFA, POCP and RA to reduce $\mathrm{CO}_{2}$-e in concrete production. The total $\mathrm{CO}_{2}$-e was estimated for RHA, POFA, POCP and RA by considering electricity used for treatment \& recycling process and transportation of materials within $100 \mathrm{~km}$ distance (Alnahhal, M.F. et al., 2018a).

Table 4. $\mathrm{CO}_{2}$ emission factor $\left(\mathrm{kg} \mathrm{CO}_{2} / \mathrm{kg}\right.$ of material) from concrete ingredients

\begin{tabular}{|l|l|l|l|l|l|l|}
\hline Granite & Sand & RA & POFA & POCP & RHA & OPC \\
\hline 0.0459 & 0.0139 & 0.0212 & 0.1102 & 0.1292 & 0.1032 & 0.8200 \\
\hline$[1]$ & {$[2,3]$} & {$[3]$} & {$[4]$} \\
\hline
\end{tabular}

[1] Flower, D.J. and Sanjayan, J.G. (2007); [2] (García-Segura, T. et al., 2014) ; [3] Alnahhal, M.F. et al. (2018a); [4] Collins, F. (2010)

\section{Recycled Aggregate Concrete in Aggressive Chemicals}

Alnahhal, M.F. et al. (2018b) found slightly higher deteriorated depth of recycled aggregate concrete (RAC) than that of normal aggregate concrete (NAC); this could be attributed chemically to the presence of additional $\mathrm{Ca}(\mathrm{OH})_{2}$ in the old mortar, and physically to the permeable voids found in the mortar attached on the RA particles, promoting a further ingress of acid ions and leading to more increase in porosity. However, the results show that the RA-based concretes containing RHA, POFA and POCP have an improvement in the deteriorated layer; the concretes with industrial byproducts as pozzolans had deteriorated layers that were about 2-4 times lower than that of RAC, depending on the cement replacement level.

After 28 days of immersion in $\mathrm{MgSO}_{4}$ solution, the compressive strength of NAC and RAC increased by about $5 \%$ and $7 \%$, respectively, while the increment was in the range of $1-3 \%$ for the specimens containing SCMs. On the other hand, after 120 days of immersion, the compressive strength decreased by about $9.2 \%$ and $11.7 \%$ for NAC and RAC, respectively, while for concretes containing RHA, POFA, and POCP, it 
decreased by about $3.0-4.8 \%, 6.9-8.2 \%$ and $4.7-6.5 \%$, respectively. It is apparent that the incorporation of RHA, POFA and POCP decreases the negative impact of MgSO4 solution on concrete.

\section{Blast Resistant OPS Concrete}

Oil palm shell concrete of grade 35 was prepared and compared with conventional crushed granite aggregate concrete for blast resistant property. The low AIV of OPS indicates its ability to disperse energy through the fibres in the OPS under compression which is one of the significant factors of concrete ingredients for ductility enhancement. A series of blast tests were conducted on OPSC and NC reinforced panels (Figure 6). For each concrete type, $1 \mathrm{~kg}$ and $10 \mathrm{~kg}$ charge explosions were performed on the same slab by considering slab response for $1 \mathrm{~kg}$ charge explosion under elastic response. Multiple cracks appeared in OPSC compared to conventional concrete due to distribution of energy through OPS in OPSC structural elements in both flexure test and blast test on panels (Alengaram, U.J. et al., 2008; Alengaram, U.J. et al., 2016b).

The response of NC slabs after $10 \mathrm{~kg}$ TNT charge weight showed totally disintegrated and shattered panels compared to intact OPSC panels. On contrary, the energy absorption of OPSC slabs could be seen through multiple cracks after 10kg explosion. The pattern of crack propagation indicated a plastic response under blast impact stress on OPSC panel. Though all cracks were not propagated along entire width, it was understood based on post inspection data that OPSC slab was failed under flexure mode. The impact resistance of OPSC slab to blast was clear and obvious as it not only had less permanent deformation but able to withstand $10 \mathrm{~kg}$ TNT with multiple cracks without any shrapnel whereas NC panel was broken into two pieces at the middle of the panel; this could be construed as positive outcome of the investigation on OPSC as potential blast resistant material due to energy absorption of OPS. Though $10 \mathrm{~kg}$ TNT created huge fire ball, there was little or no impact on the OPSC slab due to the fire ball and hence its resistance to $10 \mathrm{~kg}$ TNT was obvious.

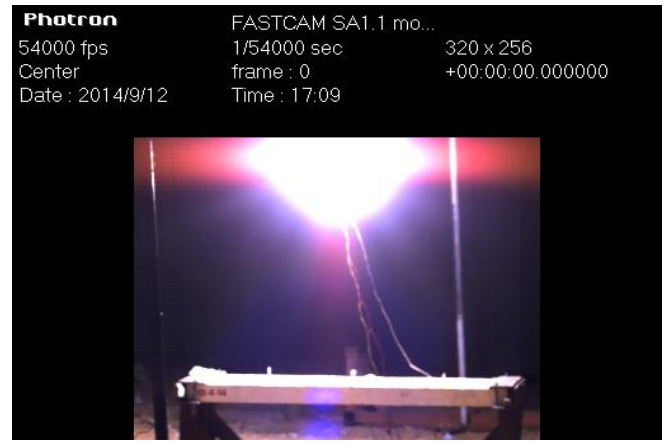

(a) Blast test on OPSC panel

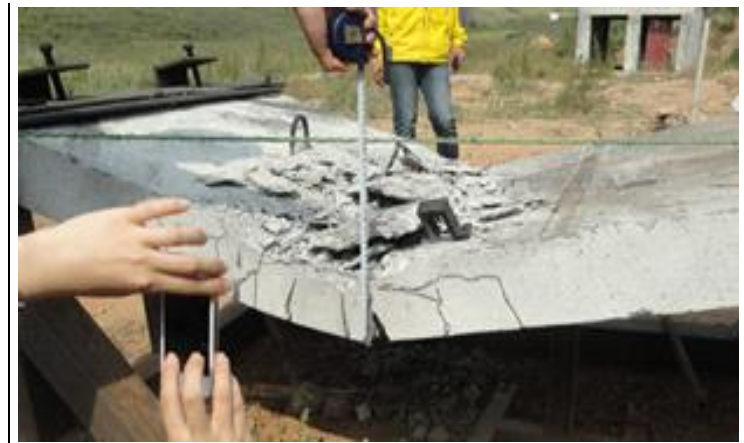

Figure 5. Shattered NC slab panel with shrapnel 


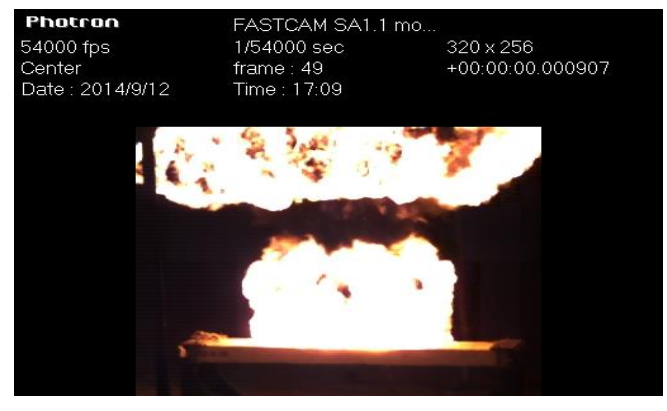

(b) Fire ball during blast

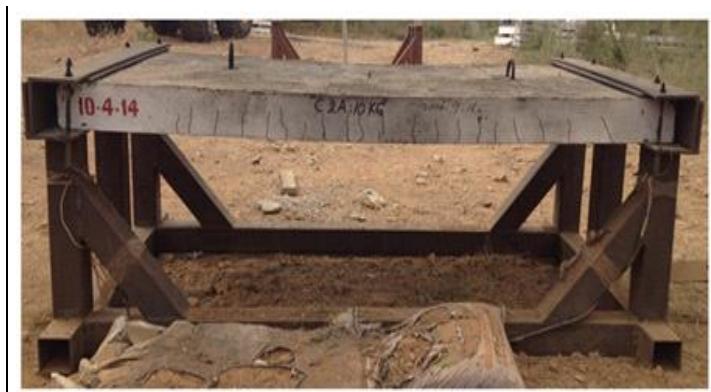

Figure 7. Intact OPSC slab panel after blast with multiple cracks

Figure 6. Blast test images-images from high speed camera

\section{Low Cost House (LCH) Using Industrial By-Products}

CICT constructed a low cost model house in University of Malaya campus (Figure 8); industrial by-products such as POCP, palm oil clinker (POC) and slag were used as (University of Malaya Media, 2016) as environmentally friendly materials. Geopolymer concrete was used for pavement blocks. Load bearing blocks were developed using POC, slag aggregate and quarry dust. The mix proportions have been filed for patent. The load bearing POC and slag bricks were manufactured at the CKYIBS (M) Sdn Bhd using hydraulic pressure and vibration on dry mix (Alengaram, U.J. et al., 2016a). POCP was used as $15 \%$ of cement replacement material for the laying of raft footing for the LCH construction; in addition, slag aggregates of sizes between 5-20 mm were used as whole replacement for conventional crushed granite aggregate in the raft footing.
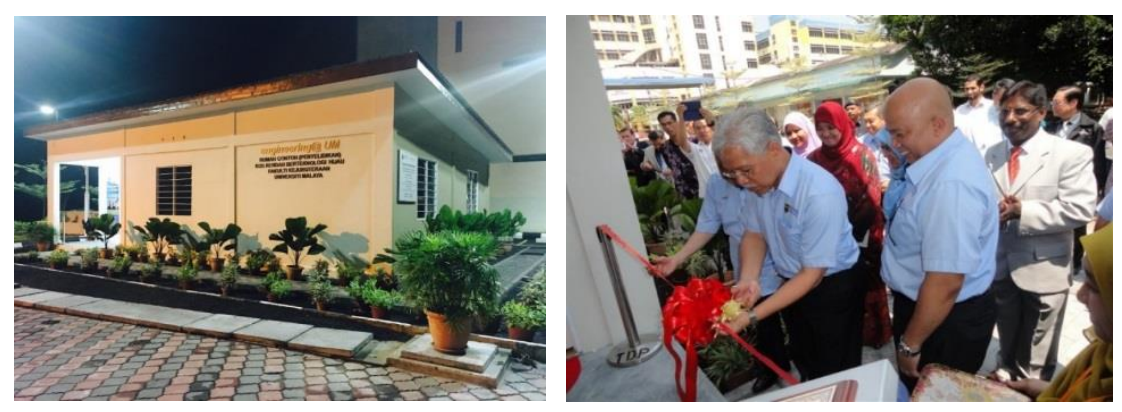

Figure 7. (a) Green technology model low cost house; (b) Launching of LCH by Former Minister of Higher Education, Malaysia, Dato' Seri Haji Idris bin Jusoh

\section{Development of Blocks Using Incinerated Bottom Ash Aggregate (IBAA)}

In the first part of that research, wet-mixed concrete was developed using IBAA as fine aggregate replacement; the results indicated that replacement of conventional sand using IBAA caused reduction in the mechanical properties such as compressive 
strength, splitting tensile strength, flexural strength and modulus of elasticity. The reduction is more significant for the case of concrete with higher compressive strength grade and higher IBAA contents, particularly at $75 \%$ and $100 \%$ replacement levels. Based on the mechanical properties results, it is recommended that the maximum replacement level of IBAA in wet-mixed concrete to be $25 \%$ and $50 \%$ for minimizing reduction in mechanical properties. Flexural tests of reinforced concrete IBAA beams also demonstrated that beams prepared with concrete containing 50\% IBAA as fine aggregate replacement were able to exhibit similar flexural performance (maximum flexural load and load-deflection relationship) as beams prepared with control concrete without any IBAA. In the second part of the work, it is showed that concrete hollow blocks containing IBAA can be successfully fabricated as well as tested for compression and diagonal tension, achieving satisfactory failure mode (Figure 8).

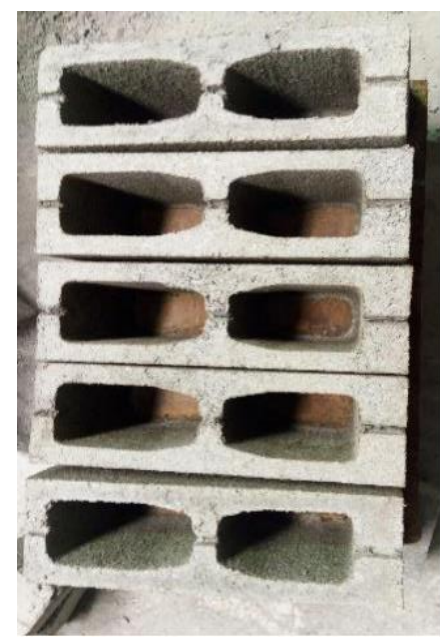

(a)
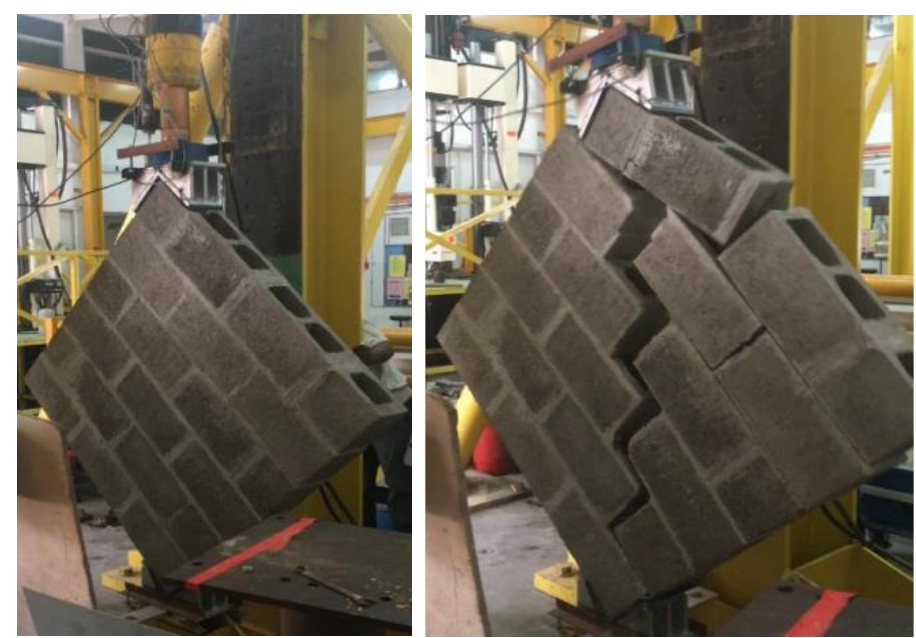

(b)

Figure 8. (a) IBAA block (b) IBAA-Block wall diagonal test set up and failure of wall under diagonal tension

\section{CONCLUSIONS}

The potential application of RHA, POFA, and POCP as a whole or partial replacement of cement is promising. More than $50 \%$ of $\mathrm{CO}_{2}$-e can be reduced by utilizing these industrial by-products in concrete. Recycled aggregate concrete deteriorates in aggressive chemical contact due to presence of more $\mathrm{Ca}(\mathrm{OH})_{2}$ compared to newly cast OPC concrete. However, utilization of pozzolans such as POFA, RHA, and POCP as cement replacement in the enhancement of durability in adverse environment is promising. Another alternative material, OPS which is an agro-waste from palm oil industry is potential that can be used as replacement of conventional coarse aggregate for impact and blast resistant concrete. The presence of fibres in OPS enables energy dissemination through concrete that enhances the impact resistance of concrete; further the ductility of OPS was also visible as the slabs with OPS showed multiple cracks 
rather than wider cracks coupled with shrapnel-evident in normal concrete. Low cost house was constructed using locally available industrial by-products; partial and whole cement replacements were carried out in normal and geopolymer concretes, respectively in the construction of $\mathrm{LCH}$. The load-deflection behaviours of the reinforced concrete beams as well as the flexural failure modes observed for beams containing 50\% IBAA were found similar to that of normal concrete.

\section{ACKNOWLEDGMENT}

The financial assistance to investigate the potential application of locally available binders through the funding of IF007-2017: Newton-Ungku Omar fund under the project titled 'Low Carbon Footprint Precast Concrete Products for an Energy Efficient Built Environment (lowcoprecon)' is acknowledged.

\section{REFERENCES}

Alengaram, U. J., Jumaat, M. Z., \& Bashar, I. I. (2016a). Low cost model house (LCH) using green technology: Centre for Innovative Construction Technology, University of Malaya.

Alengaram, U. J., Jumaat, M. Z., \& Mahmud, H. (2008). Ductility behaviour of reinforced palm kernel shell concrete beams. European Journal of Scientific Research, 23(3), 406-420.

Alengaram, U. J., Mohottige, N. H., Wu, C., Jumaat, M. Z., Poh, Y. S., \& Wang, Z. (2016b). Response of oil palm shell concrete slabs subjected to quasi-static and blast loads. Construction and Building Materials, 116, 391-402.

Alnahhal, M. F., Alengaram, U. J., Jumaat, M. Z., Abutaha, F., Alqedra, M. A., \& Nayaka, R. R. (2018a). Assessment on engineering properties and CO2 emissions of recycled aggregate concrete incorporating waste products as supplements to Portland cement. Journal of cleaner production, 203, 822-835. doi: https://doi.org/10.1016/j.jclepro.2018.08.292

Alnahhal, M. F., Alengaram, U. J., Jumaat, M. Z., Alsubari, B., Alqedra, M. A., \& Mo, K. H. (2018b). Effect of aggressive chemicals on durability and microstructure properties of concrete containing crushed new concrete aggregate and non-traditional supplementary cementitious materials. Construction and Building Materials, 163, 482-495.

Bashar, I. I., Alengaram, U. J., Jumaat, M. Z., \& Islam, A. (2014). The effect of variation of molarity of alkali activator and fine aggregate content on the compressive strength of the fly ash: palm oil fuel ash based geopolymer mortar. Advances in Materials Science and Engineering, 2014.

Bashar, I. I., Alengaram, U. J., Jumaat, M. Z., Islam, A., Santhi, H., \& Sharmin, A. (2016). Engineering properties and fracture behaviour of high volume palm oil fuel ash based fibre reinforced geopolymer concrete. Construction and Building Materials, 111, 286-297. doi: https://doi.org/10.1016/i.conbuildmat.2016.02.022

Benhelal, E., Zahedi, G., Shamsaei, E., \& Bahadori, A. (2013). Global strategies and potentials to curb CO2 emissions in cement industry. Journal of cleaner production, 51, 142-161.

Blackwelder, A. (2019, 21/03/2019). Residential Research Quarterly: March 2019. Retrieved 25/03/2019, 2019, from https://www.usgbc.org/articles/residential-research-quarterly-march2019

Celik, K., Meral, C., Gursel, A. P., Mehta, P. K., Horvath, A., \& Monteiro, P. J. (2015). Mechanical properties, durability, and life-cycle assessment of self-consolidating concrete mixtures made with blended portland cements containing fly ash and limestone powder. Cement and Concrete Composites, 56, 59-72.

Collins, F. (2010). Inclusion of carbonation during the life cycle of built and recycled concrete: influence on their carbon footprint. The international Journal of life cycle assessment, 15(6), 549-556. 
Collins, F. (2013). 2nd generation concrete construction: carbon footprint accounting. Engineering, Construction and Architectural Management, 20(4), 330-344.

Damtoft, J. S., Lukasik, J., Herfort, D., Sorrentino, D., \& Gartner, E. M. (2008). Sustainable development and climate change initiatives. Cement and concrete research, 38(2), 115-127.

Facility Executive. (2017, 07/11/2017). Global Study Asks: How Do Green Buildings Impact Thinking, Health, Sleep? $\quad$ Retrieved 25/03/2019, 2019, from http://new.greenbuildingindex.org/Files/PDF/2017/GBI\%20News(2017-11-07)-1.pdf

Flower, D. J., \& Sanjayan, J. G. (2007). Green house gas emissions due to concrete manufacture. The international Journal of life cycle assessment, 12(5), 282.

García-Segura, T., Yepes, V., \& Alcalá, J. (2014). Life cycle greenhouse gas emissions of blended cement concrete including carbonation and durability. The international Journal of life cycle assessment, 19(1), 3-12.

Islam, A., Alengaram, U. J., Jumaat, M. Z., Bashar, I. I., \& Kabir, S. A. (2015). Engineering properties and carbon footprint of ground granulated blast-furnace slag-palm oil fuel ash-based structural geopolymer concrete. Construction and Building Materials, 101, 503-521.

Kabir, S. M. A., Alengaram, U. J., Jumaat, M. Z., Yusoff, S., Sharmin, A., \& Bashar, I. I. (2017). Performance evaluation and some durability characteristics of environmental friendly palm oil clinker based geopolymer concrete. Journal of cleaner production, 161, 477-492. doi: https://doi.org/10.1016/j.jclepro.2017.05.002

Karim, M. R., Khandaker, M. U., Asaduzzaman, K., Razak, H. A., \& Yusoff, S. B. (2019). Radiological risks assessment of building materials ingredients: Palm oil clinker and fuel ash. Indoor and Built Environment, 28(4), 479-491. doi: 10.1177/1420326x18776705

Lothenbach, B., Scrivener, K., \& Hooton, R. (2011). Supplementary cementitious materials. Cement and concrete research, 41(12), 1244-1256.

McLellan, B. C., Williams, R. P., Lay, J., Van Riessen, A., \& Corder, G. D. (2011). Costs and carbon emissions for geopolymer pastes in comparison to ordinary portland cement. Journal of cleaner production, 19(9-10), 1080-1090.

Nayaka, R. R., Alengaram, U. J., Jumaat, M. Z., \& Yusoff, S. B. (2018). Microstructural investigation and durability performance of high volume industrial by-products-based masonry mortars. Construction and Building Materials, 189, 906-923.

Ng, C., Alengaram, U. J., Wong, L. S., Mo, K. H., Jumaat, M. Z., \& Ramesh, S. (2018). A review on microstructural study and compressive strength of geopolymer mortar, paste and concrete. Construction and Building Materials, 186, 550-576.

Shi, C., Jiménez, A. F., \& Palomo, A. (2011). New cements for the 21st century: The pursuit of an alternative to Portland cement. Cement and concrete research, 41(7), 750-763.

Sumesh, M., Alengaram, U. J., Jumaat, M. Z., \& Mo, K. H. (2019). Microstructural and Strength Characteristics of High-Strength Mortar Using Nontraditional Supplementary Cementitious Materials. Journal of Materials in Civil Engineering, 31(4), 04019017.

Sumesh, M., Alengaram, U. J., \& Nayaka, R. R. (2018). Effect of binder content and water-binder ratio in mortar developed using partial replacement of cement with palm oil clinker powder. Paper presented at the IOP Conference Series: Materials Science and Engineering.

University of Malaya Media. (2016, 02/09/2016). Launch of green low cost house, News of University of Malaya. Retrieved 25/03/2019, 2019, from www.um.edu.my/about-um/mediacentre/news/2016/09/02/launch-of-green-low-cost-house 